\title{
Conceptualising luxury brand attachment: scale development and validation
}

\author{
Anwar Sadat Shimul \\ lan Phau \\ Michael Lwin
}

\section{Citation}

Shimul, A. S., Phau, I., \& Lwin, M. (2019). Conceptualising luxury brand attachment: scale development and validation. Journal of Brand Management, 26(6), 675-690.

\section{ABSTRACT}

This paper aims to conceptualise consumer's luxury brand attachment by developing and validating a psychometric scale through 5 studies. Study 1 generates and selects potential scale items through literature review, thesaurus search and expert surveys. Study 2 reduces the items and assesses the dimensionality of the scale. Study 3 validates the dimensionality of the scale. Next, study 4 assesses the four types of validities (convergent, discriminate, predictive, and nomological) for the scale. Finally, study 5 examines two behavioural indicators of luxury brand attachment. The results show a parsimonious 7-item luxury brand attachment scale. The studies confirm that there are major differences among luxury brand attachment, emotional attachments to brands, and the brand attitude scales. Besides, this research demonstrates that the luxury brand attachment is a unique construct that captures the essence of consumers' emotional connection with luxury brands. The development and validation of luxury brand attachment scale fulfils an important gap in the luxury branding literature. The scale will provide meaningful insights for the luxury practitioners. The luxury brand attachment scale provides an improved measure and better understanding of consumer's attachment to the luxury brands which was not accurately measured by using general attachment scales in past studies.

Key words: Luxury brand attachment, Consumer emotion, Scale development, Validation 


\section{INTRODUCTION}

"Modern luxury is not based on age. Retail premium brands are very difficult to build. Great premium brands take time, based on the emotional connection [with the consumer that's] sustained over the long term, and on shared qualities of great design, materials and craftsmanship as well as constant innovation" - Victor Luis, CEO of the luxury brand Coach, points out the importance of emotional connection with consumers for luxury brand success (Young, 2017). Consumers' emotional intimacy with other luxury brands such as Burberry and Porsche has been evident in the literature (e.g., Straker and Wrigley, 2016; Kapferer and Bastien, 2009). In another study, BMW and Tiffany \& Co. have been identified as the top two brands that resonate with the consumers' deepest emotional desire for security, exclusivity, and ideal self-representation (Magids et al., 2015). Consumers' emotional attachment to luxury brand has been suggested as the strategic tool for enhancing brand loyalty and combating counterfeit luxury in the competitive luxury market (e.g., Kaufmann et al., 2016; So et al., 2013).

The worldwide luxury market experienced a 5\% growth in 2017, to an estimated US\$1.5 trillion globally (D'Arpizio et al., 2017). This sluggish growth rate is recognised as 'new normal' and a fundamental shift in the luxury brand market which is anticipated to continue a 2-5 percent growth through 2020 (Gibbs, 2016). Industry experts attribute this slowed growth to the evolving consumer dynamics and preferences, increased competition, economic slowdown, and influx of counterfeit luxury (Bain, 2017). The complexity escalates with the phenomenon that rich consumers are becoming less loyal (Moses, 2013) and luxury brands fail to segment and target consumers strategically (Briggs, 2016). Market experts suggest luxury brands find strategic ways to stay connected with the consumers to combat these challenges (Gomelsky, 2016).

Past studies have shown that building emotional connection with consumers is an effective strategy for the brand's long term success (e.g., Park et al., 2006; Schmalz and Orth, 2012). However, there is a lack of research on how luxury brands can build a strong and sustainable bond with the consumers. Extensive literature largely supports that an emotional connection with the consumers creates a positive impact on the brand equity (e.g., Park et al., 2010; Malär et al., 2011). The studies on brand attachment clearly indicate that the consumers' attachment differs between symbolic and functional brands (e.g., Thomson et al., 2005). Therefore, consumers' attachment for luxury brands should not be viewed and treated as same for functional brands.

Extant studies mostly utilise the brand attachment (Park et al., 2010) and emotional attachments to brands (Thomson et al., 2005) to measure the consumers' luxury brand attachment. However, the application of generic brand attachment scales within luxury context is questionable for several reasons. The unique landscape and inherent emotions laden to luxury perception are overlooked in the existing brand attachment scales (e.g., Pourazad and Pare, 2014). Moreover, the conceptualisation of luxury brands has referred to the importance of emotional connection and the distinctiveness of the consumers' perceived value within consumer-brand relationship (e.g., Vigneron and Johnson, 2004; Phau and Prendergast, 2000). Unfortunately, the essence of luxury values are not fully captured in the aforementioned measures. This research posits that the outcome might be limited if emotional attachments to brands scale is used within luxury branding 
context. The speculation has been evident in the study by Kim and Joung (2016) that, against the theoretical expectation, does not find significant relationship between luxury consumers' emotional attachment and repurchase intention. Therefore, the application of the existing scales would remain inaccurate and provide limited outcome without incorporating the conceptualisation of luxury brands into the measure. The limitations with generic measures in luxury context have been echoed in recent studies that have called for more accurate measures (e.g., Sung et al., 2015; Sreejesh et al., 2016). To the researcher's best knowledge, no past research has undertaken effort to understand the dimensions of luxury brand attachment.

This paper fulfils the aforementioned research gaps by developing and validating a new measure for luxury brand attachment with an incorporation of the key dimensions in luxury branding, for example, consumers' emotions, exclusivity, and symbolic values. Practically, luxury managers can use this improved measure to segment and target the market effectively. The following sections of this paper conceptualise the luxury brand attachment, describe the methods and five studies on the scale development procedure, discuss the implications, and provide directions for future research.

\section{CONCEPTUALISING LUXURY BRAND ATTACHMENT}

\section{Luxury brands defined}

The definition of luxury brand differs due to the diverse socio-cultural context in which consumers evaluate the brands and product categories (e.g., Kapferer and Valette-Florence, 2018; Vigneron and Johnson, 2004) as well as the subjective interpretation of the term 'luxury' (Phau and Prendergast, 2000). Luxury brand has been conceptualized with having unique traits such as emotional connection (Atwal and Williams, 2008), exclusivity (Cristini et al., 2017), conspicuousness (O'cass and Frost, 2002), status, high transaction value, and craftsmanship (e.g., Roux et al., 2017). The hierarchy pyramid for luxury brand classification suggests that the consumer's socio-economic class and purchasing power provide a segmentation method in which the top level is inaccessible luxury, the mid-level is intermediate luxury and the bottom level is accessible luxury (e.g., Alleres, 1990; De Barnier et al., 2012).

Past studies explain the luxury brand consumption from a personal aspect (Dubois and Laurent, 1994), interpersonal aspect (Mason, 1992), and socio-economic and political aspects (Hennigs et al., 2012). It is suggested that luxury brand consumption boosts consumers' ego (Eastman et al., 1999) and social recognition (Jiang and Cova, 2012). Literature also considers high price a key dimension of luxury brands (e.g. Keller, 2017), but few other studies make a counter argument that the price value of a product may not alone describe the brand as luxury (e.g., Jacoby and Olson, 1977). Furthermore, the symbolic value that consumers seek from luxury brands is seen as critical as well (Wong and Ahuvia, 1998). These factors indicate that consumers' attachment to luxury brands tend to be different from brand attachment in general. 


\section{What is luxury brand attachment?}

There is no consensus of a definition for luxury brand attachment until now. Therefore, this research adapts and adopts conceptualisation of 'attachment' from the field of psychology and marketing. The psychological theories explain attachment as the tie between a person and an object or any other components (e.g., Bowlby, 1979; Hazan and Shaver, 1994). In the marketing literature, brand attachment is defined as a long-term and commitment oriented tie between the consumer and the brand (e.g., Esch et al., 2006; Mikulincer and Shaver, 2007).

The brand attachment literature hinges on four major streams of research. The first stream shows that there is a relationship between the consumers' brand possession and a sense of self (e.g., Belk, 1988; Ball and Tasaki, 1992). Such possession and brand self-connection generate love, passion, and intimacy toward the brand (e.g., Forunier, 1998; Holt, 2002). The second stream known as Connection-Automaticity-Attachment (CAA) explains brand attachment as the combined outcome of "strong self-brand linkages and automatic retrieval of thoughts and feelings about the brand" (Park et al., 2006, p. 9). The third stream of research is an advancement of the CAA model by Park and colleagues (2010), who provide a new conceptual and methodological approach to brand attachment known as Connection-Prominence Attachment Model (CPAM). The CPAM conceptualises brand attachment with two critical indicators: $a$ ) brand-self connection and $b$ ) the prominence of brand-related thoughts and feelings. The fourth stream of research pioneered by Thomson et al. (2005) emphasises on the emotional aspects of the attachment and names the construct as emotional attachments to brands. Later on, Malär et al. (2011) validate the construct with identifying consumers' perceived brand selfcongruence as the predictor of the consumers' emotional attachments to brands.

The conceptualization of luxury brand demonstrates that the inherent traits of luxury brands are very unique and the benefits that consumers seek from luxury brands are mostly emotional (e.g., Murray, 2016; Tsai, 2005). Studies on luxury consumer-brand relationships show the strength of symbolic value, self-expression and conspicuousness on consumers' purchase intention (e.g., Cheah et al., 2015; Hudders, 2012). In addition, consumers seek hedonism, status, and uniqueness from luxury brands and they believe that a strong and enduring emotional bond with the brand will fit their actual self-image and help them to attain ideal selfimage (e.g. Seo and Buchanan-Oliver, 2015; Liu et al., 2012). These distinctiveness of luxury brands clearly indicates that consumers' emotional connection is fundamental in designing the luxury brand attachment measurement. Building on this idea and considering the predominant emotion laden connection between consumers and luxury brands, luxury brand attachment is defined as "the emotional bond that connects a consumer to the luxury brand and develops deep feelings within the consumer toward the luxury brand". A set of theories from social psychology (e.g., attachment theory, theory of emotion, self-expansion theory) were examined to identify the theoretical underpinning of luxury brand attachment.

\section{Distinction between luxury brand attachment and other related constructs}

Luxury brand attachment is different from emotional attachments to brands in several ways. First, the conceptualisation of emotional attachments to brands (Thomson et al., 2005) encompasses three major 
dimensions of emotions (affection, passion, and connection). Although few of these emotions might be applicable for luxury brand attachment, the 10-item measure for emotional attachments to brands does not consider the key traits of luxury brands (e.g. exclusiveness, exquisiteness, status, achievement) that elicit a particular type of emotion (e.g. joy, devotion, pleasure, infatuation).

Second, the desire for proximity maintenance and feeling of separation distress have been extensively emphasised in the attachment literature (Bowlby, 1979). It has been evident from the literature that luxury brands provide uniqueness and social status to the consumers and thus they show willingness to prolong the relationship (i.e. proximity maintenance) for a continuous achievement (Hung et al., 2011). In addition, when a luxury brand becomes unavailable it creates a sense of loss (i.e. separation distress) in the consumers' mind (e.g., Rindfleisch et al, 2009). Unfortunately, the emotional attachments to brands scale does not include these two elements. Thus, it limits the researchers' and practitioners' ability to accurately measure luxury brand attachment.

Overall, emotional attachments to brands scale does not reflect the luxury consumers' high involvement, strong emotional connection, and perceived exclusivity. A similar argument is applicable for distinguishing luxury brand attachment from brand attachment (Park et al., 2010). Although brand-self connection and brand prominence are relevant to luxury brand attachment, the scale developed by Park et al. (2010) does not capture above discussed essence of luxury brands. This research acknowledges that luxury brand attachment is related to but conceptually distinct from general brand attachment and emotional attachments to brands.

The similarities and differences between brand attachment and brand love have been critically reviewed by Moussa $(2015$, p. 69) who notes that brand attachment and brand love are "the same core knowledge product offered under different brand names". Whereas Moussa's (2015) arguments intrigue academic debate, this research admits the similarities between the constructs as well as acknowledges their distinct conceptualisations which have been widely accepted in the literature (e.g., Thomson et al., 2005; Carroll and Ahuvia, 2006; Park et al., 2010; Batra et al., 2012; Romaniuk, 2013). This research distinguishes luxury brand attachment and brand love in terms of their underpinning theories and conceptual development. First, the conceptualisation for luxury brand attachment lies within the psychological theories of human attachment (Bowlby, 1979; Ainsworth, 1982), whereas brand love is conceptualised with the theories of interpersonal love (Carroll and Ahuvia, 2006) and romantic love (Sarkar et al., 2012). Thus, noting the distinct theoretical conceptualisations, Albert et al (2008) state that attachment is not directly related to the consumers' feeling of love toward the brand. Second, consumer satisfaction which is a post-consumption phenomenon is considered a prerequisite for brand love (Carroll and Ahuvia, 2006; Roy et al., 2012). By contrast, luxury brand attachment does not hinge on the consumption or satisfaction, because consumers may build a psychological connection and emotional proximity with aspirational luxury brands as well (Sreejesh et al., 2016). Third, luxury brand attachment is largely built on the consumers' emotional bond with the luxury brands, whereas brand love encompasses both the cognitive (idealisation) and emotional (affective proximity) components of consumers (Albert et al., 2008). Nevertheless, few items of brand love scale (Batra et al., 2012) are relevant to 
the scope of luxury brand attachment due to the presence of self-expressive and hedonic nature of luxury brands.

Several studies distinguish brand attachment from brand attitude (e.g., Park et al., 2010, Thomson et al., 2005). The conceptualisation of luxury brand attachment assumes similar distinction between the constructs. First, luxury brand attachment develops over the time which is not a requirement for brand attitude. Second, luxury brand attachment involves consumers' emotional connection to the brand, whereas brand attitude is rather an overall evaluation of the brand. Third, consumers' self-brand congruence has been identified as the predictor of luxury brand attachment, which is not applicable for brand attitude. Fourth, luxury brand attachment results separation distress for the consumers which brand attitude does not upshot. Finally, the effect of luxury brand attachment is stronger than that of brand attitude. Consumers with high luxury brand attachment are expected to stay loyal, advocate the brand to others, and show willingness to pay premium price for the brand. By contrast, brand attitude does not result in any such behavioural intentions.

\section{METHOD}

This research follows the scale development guideline suggested by Churchill (1979) and DeVellis (2003). At first, the consumers' notion of luxury brand attachment is assessed through in-depth interview of consumers $(n=17)$. Attempts have been made to ensure the distinction of luxury brand attachment from the generic brand attachment. Then, a series of five studies are undertaken to develop the scale. Study 1 generates and selects potential scale items through literature review, thesaurus search and expert surveys. Study $2(n=252)$ reduces the items and assesses the dimensionality of the scale. Study $3(n=222)$ validates the dimensionality of the scale. Next, study $4(n=291)$ assesses the four types of validities (convergent, discriminate, predictive, and nomological) for the scale. Finally, study $5(n=252)$ examines two behavioural indicators of luxury brand attachment. The respondents in the aforementioned five studies consisted of luxury branding academics, doctoral students, industry practitioners, and luxury consumers. A summary of the scale development procedure is presented in the Table 1. 
Table 1 - Summary of scale development procedure

\begin{tabular}{|c|c|}
\hline \multicolumn{2}{|r|}{ Study 1} \\
\hline Purpose & Item generation and selection \\
\hline Respondents & luxury branding academics $(n=3)$ and industry experts $(n=2)$ \\
\hline Stimuli & Explained working definitions of concepts \\
\hline Methods & Literature review, thesaurus search, expert survey \\
\hline Results & A pool of 107 items were populated \\
\hline \multicolumn{2}{|r|}{ Study 2} \\
\hline Purpose & Item reduction and assessment of scale dimensionality \\
\hline Respondents & Phase 1: luxury brand academics $(n=2)$ and doctoral students $(n=3)$ \\
\hline & Phase 2: luxury consumer panel $(n=94)$ \\
\hline & Phase 3: Academics $(n=8)$, doctoral students $(n=16)$, industry practitioners $(n=10)$ \\
\hline & Phase 4: luxury consumer panel $(n=252)$ \\
\hline Stimuli & Phase 1-3: Explained working definitions of concepts \\
\hline & Phase 4: Giorgio Armani sunglasses \\
\hline Methods & EFA, reliability analysis (Cronbach's), correlations. \\
\hline Results & $\begin{array}{l}\text { Retained: } 63 \text { items in phase 1, } 27 \text { items in phase } 2 \text {, and } 22 \text { items in phase } 3 . \text { An EFA revealed one } \\
\text { dimensional } 16 \text { items in phase } 4 .\end{array}$ \\
\hline \multicolumn{2}{|r|}{ Study 3} \\
\hline Purpose & Validation of the scale dimensionality \\
\hline Respondents & Luxury consumer panel $(n=222)$ \\
\hline Stimuli & Giorgio Armani sunglasses \\
\hline Methods & CFA with AMOS 24 \\
\hline Results & CFA on the 16 items resulted 7 items with good model fit. \\
\hline \multicolumn{2}{|r|}{ Study 4} \\
\hline $\begin{array}{l}\text { Purpose } \\
\text { Items }\end{array}$ & $\begin{array}{l}\text { Scale validation } \\
7 \text { items }\end{array}$ \\
\hline Respondents & Luxury consumer panel $(n=291)$ \\
\hline Stimuli & Rolex wristwatch \\
\hline Methods & EFA, reliability analysis (Cronbach's), and CFA with AMOS 24 \\
\hline Results & Convergent, Discriminant, Predictive and Nomological validities were established. \\
\hline \multicolumn{2}{|r|}{ Study 5} \\
\hline $\begin{array}{l}\text { Purpose } \\
\text { Items }\end{array}$ & $\begin{array}{l}\text { Behavioural indicators of luxury brand attachment } \\
7 \text { Items }\end{array}$ \\
\hline Respondents & Luxury consumer panel $(n=252)$ \\
\hline Stimuli & Giorgio Armani sunglasses \\
\hline Other & Brand satisfaction, brand loyalty \\
\hline Methods & CFA and structural model testing with AMOS 24 \\
\hline Results & $\begin{array}{l}\text { Brand satisfaction positively influences luxury brand attachment and brand loyalty. Luxury brand } \\
\text { attachment positively influences brand loyalty. }\end{array}$ \\
\hline
\end{tabular}




\section{ASSESSING CONSUMERS' NOTION OF LUXURY BRAND ATTACHMENT}

What is the consumers' understanding of luxury brand attachment? Does their perception align with the conceptual notion of this research? A total of 17 consumers ( 9 female, 8 male, average age 27 years) were interviewed to address those questions. The responding participants had past or ongoing experiences with luxury brands. However, they were provided with a brief on the nature and conceptualisation of luxury brands with some examples in the beginning of the interview for a better understanding of the research goal. In step one, the participants were asked in an open-ended question to provide the name of a luxury brand with which they feel a sense of attachment. In step two, they were asked to describe their feelings toward that particular brand with a set of key words. For clarity and simplicity, three sample attachment-expressing words (bond, connection, and attached) were provided to the participants. In the final step, the participants were asked to write statements with each of the words that would best describe their feelings toward the luxury brand. Hence, it was imperative to investigate whether the consumers' notion of luxury brand attachment would be different from the attachment to a non-luxury brand. Therefore, the participants were asked to repeat the above mentioned three steps within the context of a non-luxury brand. This has been done to establish the separation of luxury brand attachment from the generic brand attachment.

The collected responses showed that consumers identified Louis Vuitton, Gucci, Giorgio Armani, Dolce\&Gabbana, Swarovski, and Rolex as their chosen luxury brands to which they have a sense of attachment. Overall, the participants expressed their luxury brand attachment as a strong affinity and intimate desire to stay close to the brand. They also described their feeling to the attached luxury brand with keywords such as - 'love', 'addiction', 'devotion', 'prestige', 'fancy', 'desire', 'worship', 'exclusiveness', 'achievement', 'accomplishment' etc. For instances, one participant noted her attachment to Louis Vuitton as - "I am addicted to LV products". Another participant pointed that his "Rolex wristwatch provides prestige and social recognition". Most of the respondents highlighted that the unique traits of the luxury brands, such as exclusiveness, limited edition, and uniqueness, generate a sense of desire and proximity toward the brand. The interview responses also showed that the participants' attachment toward non-luxury brands primarily centred on the perceived benefits and functionality of the brand. The participants mentioned the ease of search with Google, consistent and reliable performance from Apple (iPhone, Macbook), durability of Nike, and the dental protection provided by Colgate as the key drivers of perceived attachment to these brands. Although, few participants indicated their emotional connection to the non-luxury brands (e.g., Google is a part of my life), the level of emotion was not only mild but also resulted from the utilitarian nature of the brand (e.g., Google search makes my life easy).

In line with the extant literature, it has been found in this research that consumers' luxury brand attachment is mostly emotion laden. Moreover, the sense of achievement, status-seeking, conspicuousness and exclusivity are the key catalysts behind the consumers' aspiration for and attachment with the luxury brands. In summary, it has become evident that the emotional aspects are prominent in the consumers' notion of luxury brand attachment. 


\section{STUDY 1 - ITEM GENERATION AND SELECTION}

In this study, a set of potential scale items were generated following the scale development procedure suggested by Devellis (2003). This was done through an extensive literature reviews (Churchill, 1979), thesaurus searches (Wells et al., 1971), and expert surveys (Chen and Wells, 1999; Churchill, 1979).

First, the extant psychology literature on "human attachment" was studied to understand the basic conceptualisation of attachment. Following that the literature on attachment theory (e.g., Bowlby, 1979; Ainsworth, 1982), theory of emotion (e.g., Parrott, 2001), self-expansion theory (e.g., Aron and Aron, 1986), social identity theory (e.g., Tajfel, 1974), and self-congruence theory (e.g., Sirgy, 1982) were examined to establish the theoretical foundation of luxury brand attachment.

Second, the branding literature relevant to brand-self congruity, general brand attachment, emotional attachments to brands, brand love, brand attitude, brand authenticity, brand community engagement, brand satisfaction, brand loyalty, brand trust, and such other consumer-brand relationship constructs were searched to identify the dimensions and keywords that might be relevant to the luxury brand attachment. Additionally, existing scales on brand attachment (Orth et al., 2010; Park et al., 2010; Lacœuilhe, 2000) and emotional attachments to brands (Thomson et al., 2005) were consulted to generate items for the luxury brand attachment scale. The adoption of general brand attachment items might be questionable due to the limited transferability from non-luxury to luxury context. However, these scale items cannot be ignored as some of them capture the feelings that are attached to luxury brands.

Third, luxury branding literature was studied to comprehend the nature of the relationships that consumers build with the luxury brands. In particular, the emotional aspects (benefits, desire, aspiration etc.) were examined throughout the review. Moreover, research was conducted on newspaper, magazine, blog and other popular press through which various applications of 'feeling wheel' (Willcox, 1982) and 'Plutchik's Flower' (Plutchik, 1980) were found and considered for scale item generation. A set of 24 words (e.g., pleasure, self-expression, distinctiveness, elegancy, success, face saving, pleasurable benefits) were generated though the literature search.

With an understanding of the emotional nature of the luxury brand attachment, a thesaurus search was conducted to populate the words that reflect human emotion and might be relevant to the consumers' expression of luxury brand attachment. A total of 73 words (e.g., affinity, close, delight, exquisite, fond, intimate, joy, attractive, excitement, zeal) were generated in this process.

Furthermore, three academics and two industry experts in luxury branding were surveyed to populate more scale items. They proposed 29 words of which 19 were already enlisted through the literature review and thesaurus search. Thus, the expert surveys generated 10 additional items (e.g., conformity, achieve, aspiration). 
Next, a pool of 107 statements were composed with the populated words. As suggested by Brakus et al. (2009), some of the items were reworded to maintain linguistic style and make relevant to the consumer-branding context. Items were also looked at critically for eliminating potential ambiguity, double-barrelled items, and multiple negatives (DeVellis, 2003).

\section{STUDY 2 - ITEM REDUCTION AND ASSESSMENT OF SCALE DIMENSIONALITY}

The twofold goal of the study 2 was to reduce the items generated in the study 1 and to determine the dimensionality of the luxury brand attachment scale. This was achieved in 4 sequential phases.

Four different types of respondents were targeted for data collection throughout the 4 phases: (1) Luxury academics, who prominently published in the luxury branding area, were identified through Google Scholar search. (2) Academics and doctoral students in luxury branding from academic conferences (e.g. Australia New Zealand Marketing Academy Conference, World Marketing Congress, The Mystique of Luxury Brands Conference, and Korean Scholars of Marketing Science Conference). (3) The luxury consumers were recruited through an online consumer panel. (4) Industry practitioners were contacted through Linkedln and the past years' CV books (2012-2015) of two large European universities that offer postgraduate degree in Luxury Marketing Management.

In the phase 1, two luxury branding academics and three doctoral students rated the items for the initial screening and face validity check. Based on their judgements, the number of items were reduced from 107 to 63. Items were deleted primarily for two reason: first, the intended meaning of multiple items were duplicated; and second, some items do not potentially capture the essence of luxury brand attachment.

In the phase 2 , the 63 items were presented to an online panel of luxury consumers $(n=94)$. The respondents were provided with the conceptual definition of the luxury brand attachment in the beginning of the survey. They were then asked to think of and write the name of a luxury brand they are heavily attached to. The name of three luxury brands (Giorgio Armani, Gucci, and $D \& G$ ) were provided for a better understanding. Using a seven-point Likert scale ( $1=$ Not representative at all, and $7=$ Clearly representative), the respondents evaluated whether the statements were good or bad measures of their luxury brand attachment. An additional option (NA = Not applicable) was also added to the Likert scale. A total of 27 items which had an average value greater than 4.0 were retained for the next phase.

In the phase 3 , another panel of luxury branding academics $(n=8)$, doctorial students $(n=16)$, and industry practitioners $(n=10)$ were surveyed for testing the content validity. The respondents were asked to rate the items on a seven-point Likert scale ( $1=$ Not representative at all, and $7=$ Clearly representative), and to select the five most important items that would represent the luxury brand attachment. They were also asked to provide additional comments on wordings and potential dimensionality of the scale. Based on the rating and qualitative comments from the experts, 5 items were removed and thus 22 items were retained in this phase. 
Notably, 3 respondents predicted multidimensionality of the scale. Few experts suggested the scale items include 'this luxury brand' to provide a stronger contextual cues. However, two academics in luxury branding who are also expert in scale development procedure advised customising the items within the context of the brand. Therefore, the items reported in this paper (Table 2 and 4) are written in generic format (e.g., When I think of this luxury brand, I feel a sense of joy), but the operationalisation in specific studies included the brand name in the items (e.g., When I think of Rolex, I feel a sense of joy). In addition, few linguistic issues were fixed to maintain consistency amongst the items.

In the phase 4, attempts were made to reduce the items further and to identify the dimensionality of the scale. However, as prescribed by past studies (e.g., Thomson et al., 2005), one particular brand was used in this phase to assess the consumers' luxury brand attachment. For selecting an appropriate brand, a pre-test $(n=61)$ was conducted with a list of 38 product categories from 32 luxury brands. The most familiar brands (Rolex, Giorgio Armani, Dolce\&Gabbana, Prada, Gucci, Chanel, Christian Dior, and Guess) and product categories (sunglasses, jeans, watches, undergarments, bags, shoes, and fragrances) were identified through the pre-test. Two academics in luxury branding independently rated the brands and product categories through which Giorgio Armani sunglasses was selected as a gender neutral, affordable, and appropriate luxury brand to be used as the stimulus in the survey of this study. Thereafter, a new set of data was collected from a luxury consumer panel in this phase. The sequence of items in the questionnaire was randomised to avoid the order effect. A real-life advertisement of Giorgio Armani sunglasses was presented as the stimulus in the beginning of the survey. Hence, the respondents' brand likeability (Martin and Stewart, 2001) was tested as a screening question. This was done with the notion that "self-concept congruence is greater for most preferred product brands than for least preferred product brands" (Dolich, 1969, 80). Only the respondents with minimum score of 4.0 out of 7.0 on brand likeability were considered for further analysis. The valid and useable respondents $(n=252)$ comprised of $54.8 \%$ female and $84.9 \%$ within the $18-30$ age bracket. This age group reflects the segment that has been identified as the most potential future market segment to buy luxury goods and services (e.g., Sarkar, 2017; Hung et al, 2011).

An internal criterion was applied as the first step of the measurement procedure to assess the 22 items. An item-to-total correlation test was conducted and one item with low correlation $(<.40)$ was eliminated. Then an Exploratory Factor Analysis (EFA) was conducted with Principle Component Analysis, Varimax rotation and factor loading greater than 0.40 to assess the remaining 21 items. The sample adequacy (KMO >0.70) and reliability (Cronbach alpha $>0.70$ ) of the constructs were satisfied. Bartlett's test of sphericity was statistically significant $(p<0.05)$ for all the constructs. Interestingly, there were no cross-factor loading; the final set of items reflected one factor solution (eigenvalue $>1$ ) with 16 items loading $0.580-0.915$ as well as explaining $71.75 \%$ variations. In addition, the inter-item correlation matrix demonstrated satisfactory item-item correlation ( $>0.20$ ). A double check on the items' mean scores and standard deviations (DeVellis, 2003) did not show any extreme value either way. However, the considerably high level of Cronbach's Alpha (0.973) suggested that the initial scale might be unnecessarily long. This issue was addressed in the study 3 which validates the dimensionality of the scale through a newly collected data set. 


\section{STUDY 3 - VALIDATION OF THE SCALE DIMENSIONALITY}

The purpose of study 3 was to confirm the stability of the dimensions of the luxury brand attachment scale. This study followed a similar survey structure used in the phase four of the study 2. A real life Giorgio Armani sunglasses advertisement was used as the stimulus. Again, only the respondents with minimum score of 4.0 out of 7.0 on brand likeability were considered for further analysis. A new set of data was collected from an online luxury consumer panel. Among the valid and useable respondents $(n=222), 52.3 \%$ were female and $86.0 \%$ were within the age range of $18-30$ years.

First, an EFA was conducted with Principle Component Analysis, Varimax rotation and factor loading greater than 0.40 to assess the 16 items. The sample adequacy (KMO $>0.70)$ and reliability (Cronbach alpha $>0.70)$ of the constructs were satisfied, and the Bartlett's test of sphericity was statistically significant $(p<0.05)$ for all the constructs. No cross-factor loading emerged; the final set of items reflected one factor solution (eigenvalue $>1$ ) with 16 items loading $0.563-0.908$ as well as explaining $70.74 \%$ variations. Further, an item-to-total correlation test was conducted and all items had satisfactory correlations (>.40). The Cronbach Alpha level (0.972) for this sample was very high also. Besides, the items' mean scores and the standard deviations did not show any extreme value either way.

Next, a Confirmatory Factor Analysis (CFA) was undertaken with AMOS 24.0. Throughout the CFA, 9 items were deleted due to high modification indices or low standardized loadings (cut-off: 0.40 ). Finally, the CFA assessed a one-factor measurement model and provided an excellent model fit with $x^{2}=17.215, \mathrm{df}=14, \mathrm{X}^{2} / \mathrm{df}=1.23$, $\mathrm{CFI}=0.998, \mathrm{AGFI}=0.956, \mathrm{TLI}=0.996, \mathrm{RMR}=0.044, \mathrm{SRMR}=0.019, \mathrm{RMSEA}=0.032$, and PClose $=0.698$ (Hu and Bentler, 1999). Moreover, the composite reliability $(C R)=0.945, A V E=0.711, \operatorname{Max} R(H)=0.956$, and strong coefficient of determination for individual item (standardized loadings from 0.70 to 0.93 ) provided satisfactory convergent validity for the scale (Fornell and Larcker, 1981).

\section{STUDY 4 - SCALE VALIDATION}

The discriminant, nomological, and predictive validity of the luxury brand attachment scale were established in the study 4. Moreover, it is imperative to establish that luxury brand attachment scale items do not depend on the brand, product category or respondents. Therefore, a new set of data was collected with a different stimulus from a new online luxury consumer panel. This study also followed a similar survey structure used in the study 3. A real life Rolex wristwatch advertisement was used as the stimulus. The respondents with minimum score of 4.0 out of 7.0 on brand likeability were considered for further analysis. The valid and useable respondents ( $n=291$ ) consisted of $55.3 \%$ female and $87.8 \%$ respondents were within the age range of $18-30$ years.

Discriminant validity of the luxury brand attachment scale was established through an EFA and CFA of the construct by comparing against the scales for emotional attachments to brands and the brand attitude. The 
10-item emotional attachments to brands (Thomson et al., 2005) was measured on a scale of 1 (not at all) to 7 (very well). In addition, the 5-item attitude toward the brand (Erdem and Swait, 2004) was employed on a 7 point Likert scale ( $1=$ strongly disagree to $7=$ strongly agree). First, an EFA was conducted for the three constructs with Principle Component Analysis, Varimax rotation and factor loading greater than 0.60 . The sample adequacy (KMO > 0.70) and reliability (Cronbach alpha $>0.70)$ of the constructs were satisfied, and the Bartlett's test of sphericity was statistically significant $(p<0.05)$ for all the constructs. The factor loadings revealed three distinct constructs without any cross-factor loading (Table 2). Thus, the EFA assured the distinctiveness of the luxury brand attachment, emotional attachments to brands and brand attitude.

Table 2 - EFA with Luxury Brand Attachment (LBA) items and measures for Emotional Attachment to Brands (EAB) and Brand Attitude (BAtt)

\begin{tabular}{|c|c|c|c|}
\hline & \multicolumn{3}{|c|}{ Factors } \\
\hline & $\mathrm{EAB}$ & LBA & BAtt \\
\hline Bonded & 0.855 & - & \\
\hline Connected & 0.850 & & \\
\hline Attached & 0.832 & & \\
\hline Delighted & 0.810 & & \\
\hline Peaceful & 0.804 & & \\
\hline Loved & 0.796 & & \\
\hline Affectionate & 0.790 & & \\
\hline Passionate & 0.790 & & \\
\hline Friendly & 0.772 & & \\
\hline Captivated & 0.700 & & \\
\hline When I think of this luxury brand, I feel a sense of joy & & 0.804 & \\
\hline I feel this luxury brand helps me achieve what I want & & 0.798 & \\
\hline I am deeply passionate about this luxury brand & & 0.779 & \\
\hline I have a deep emotional connection to this luxury brand & & 0.768 & \\
\hline I would feel a sense of loss if this luxury brand is no longer available & & 0.744 & \\
\hline I am deeply in love with this luxury brand & & 0.744 & \\
\hline I feel a sense of exquisiteness from this luxury brand & & 0.635 & \\
\hline This brand's product claims are believable & & & 0.874 \\
\hline This brand has a name you can trust & & & 0.857 \\
\hline This brand doesn't pretend to be something it isn't & & & 0.853 \\
\hline This brand delivers what it promises & & & 0.839 \\
\hline Over time, my experiences with this brand have led me to expect it to keep its & & & 0.625 \\
\hline Cronbach's a & 0.953 & 0.919 & 0.888 \\
\hline Eigenvalues (\% of Variance) & & 70.757 & \\
\hline KMO & & 0.926 & \\
\hline Bartlett's Test of Sphericity & & & \\
\hline Approx. Chi-Square & & 5584.41 & \\
\hline$d f$ & & 231 & \\
\hline Sig. & & 0.000 & \\
\hline
\end{tabular}

Extraction Method: Principal Component Analysis.

Rotation Method: Varimax with Kaiser Normalization.

a. Rotation converged in 5 iterations. 
To ensure convergent validity, the measurement model was analysed with the three constructs. The model revealed a good fit as well: $\mathrm{X} 2=401.731, \mathrm{df}=195, \mathrm{X} 2 / \mathrm{df}=2.060, \mathrm{CFI}=0.963, \mathrm{TLI}=0.956, \mathrm{SRMR}=0.060$, and RMSEA $=0.060$ (Hu and Bentler, 1999). As shown in the Table 3, the composite reliability (CR) for the three constructs were between 0.884 and 0.949 and thus the internal consistencies were assured (Hair et al., 2010). All the square root of the Average Variance Extracted (AVE) values were higher than the pair-wise interconstruct correlations in assurance of discriminant validity among the three constructs (Fornell and Larcker, 1981). Furthermore, the AVE value for the constructs were above 0.60 and thus the results further attested the convergent validity (Malhotra, 2010).

Table 3 - Composite reliability and discriminant validity of construct measures (Study 4)

\begin{tabular}{lccccc}
\hline & CR & AVE & EAB & LBA & BAtt \\
\hline Emotional Attachment to Brands (EAB) & 0.949 & 0.654 & $\mathbf{0 . 8 0 9}$ & & \\
Luxury Brand Attachment (LBA) & 0.916 & 0.614 & 0.344 & $\mathbf{0 . 7 8 3}$ & $\mathbf{0 . 7 7 9}$ \\
Brand Attitude (BAtt) & 0.884 & 0.607 & 0.681 & 0.224 & \\
\hline
\end{tabular}

To assess the nomological validity of the scale, the relationship between consumers' perceived selfcongruence and luxury brand attachment was tested. Theoretically, consumers' perceived self-congruence should have a positive influence on luxury brand attachment. Perceived self-congruence with the brand refers to the degree of match between a consumer's perception of a brand and the perception they have of themselves (Sirgy, 1982). The more the brand reflects the consumer's self, the greater the personal connection to the brand (Park et al., 2010). Sirgy et al.'s (1997) 5-item scale (Cronbach's $a=0.83$ ) was used to measure actual self-congruence as well as was adapted to measure the ideal self-congruence on 7 point Likert scale (1 $=$ strongly disagree to $7=$ strongly agree). $\mathrm{A}$ linear regression test showed a significant positive relationship between perceived actual self-congruence and luxury brand attachment (Adjusted $R^{2}=0.394, \beta=0.629, t=$ $13.760, p<0.001)$. A similar relationship was found between perceived ideal self-congruence and luxury brand attachment (Adjusted $R^{2}=0.489, \beta=0.701, t=16.689, p<0.001$ ).

Finally, the predictive validity was assessed through testing the relationship between luxury brand attachment and consumer advocacy. Consumer advocacy has been explained in the marketing literature as the consumers' tendency to offer passionate referral and helping behaviour that benefit other consumers in their choices and consumptions (e.g. Chelminski and Coulter, 2011; Price et al., 1995). Scholars argue that consumers are willing to advocate the brand if they feel an affection to the brand (e.g., Shukla et al., 2016). Therefore, it was postulated that luxury brand attachment would predict consumer advocacy. The 5-item consumer advocacy (Chelminski and Coulter, 2011) was measured on a 7 point Likert scale $(1=$ strongly disagree to $7=$ strongly agree). The regression result showed a significant positive relationship between luxury brand attachment and consumer advocacy (Adjusted $R^{2}=0.467, \beta=0.685, t=15.984, p<0.001$ ). The EFA and CFA loadings for the luxury brand attachment scale in study 2, 3 and 4 are summarised in Table 4. 
Table 4 - Summary psychometric data for the 7-item luxury brand attachment scale

\begin{tabular}{|c|c|c|c|c|c|}
\hline & \multirow{2}{*}{$\begin{array}{c}\text { Study } 2 \\
\mathrm{n}=252 \\
\text { Giorgio }\end{array}$} & \multicolumn{2}{|c|}{$\begin{array}{l}\text { Study } 3 \\
\mathbf{n}=222 \\
\text { Giorgio }\end{array}$} & \multicolumn{2}{|c|}{$\begin{array}{l}\text { Study } 4 \\
\mathbf{n}=291 \\
\text { Rolex }\end{array}$} \\
\hline & & EFA loading & $\begin{array}{c}\text { CFA } \\
\text { loading }\end{array}$ & $\begin{array}{c}\text { EFA } \\
\text { loading }\end{array}$ & $\begin{array}{c}\text { CFA } \\
\text { loading }\end{array}$ \\
\hline I am deeply passionate about this luxury brand & 0.915 & 0.929 & 0.930 & 0.864 & 0.800 \\
\hline I am deeply in love with this luxury brand & 0.897 & 0.904 & 0.900 & 0.873 & 0.810 \\
\hline When I think of this luxury brand, I feel a sense of joy & 0.887 & 0.904 & 0.890 & 0.888 & 0.890 \\
\hline I have a deep emotional connection to this luxury brand & 0.888 & 0.862 & 0.840 & 0.884 & 0.830 \\
\hline I would feel a sense of loss if this luxury brand is no longer & 0.812 & 0.854 & 0.830 & 0.764 & 0.710 \\
\hline $\begin{array}{l}\text { available } \\
\text { I feel this luxury brand helps me achieve what I want }\end{array}$ & 0.841 & 0.843 & 0.800 & 0.843 & 0.820 \\
\hline I feel a sense of exquisiteness from this luxury brand & 0.744 & 0.758 & 0.700 & 0.639 & 0.580 \\
\hline Cronbach's a & 0.973 & 0.944 & & 0.919 & \\
\hline Eigenvalues (\% of Variance) & 71.752 & 75.046 & & 68.318 & \\
\hline $\mathrm{KMO}$ & 0.961 & 0.934 & & 0.901 & \\
\hline Bartlett's Test of Sphericity & & & & & \\
\hline Approx. Chi-Square & 4583.18 & 1355.132 & & 1553.69 & \\
\hline$d f$ & 120 & 21 & & 21 & \\
\hline Sig. & 0.000 & 0.000 & & 0.000 & \\
\hline
\end{tabular}

\section{STUDY 5 - BEHAVIOURAL INDICATORS OF LUXURY BRAND ATTACHMENT}

A review of the literature indicates brand satisfaction as the antecedent and brand loyalty as the outcome of luxury brand attachment. Underpinned by the Expectancy-Disconfirmation Paradigm (Oliver, 1980), brand satisfaction is defined as the consumers' post-purchase experience whether a particular brand fulfils the consumer's expectations. Past literature suggests that a pleasurable brand experience (i.e. brand satisfaction) generates affection (i.e. attachment) toward the brand (e.g., Belaid and Behi, 2011). In addition, studies largely posit brand loyalty as a key outcome of brand attachment (e.g. Park et al., 2010). Studies have utilised the Social Exchange Theory to conceptualise brand loyalty as the consumers' strong commitment to patronage a brand repeatedly (Oliver, 2010). Brand attachment elicits a sense of happiness and the consumers wish to prolong the relationship with brand (Aksoy et al., 2015). Based on the aforementioned arguments, the luxury brand attachment is also expected to predict similar outcome in this study. Further, this study revisits the widely debated proposition whether satisfied consumers necessarily become brand loyal (e.g. Mittal, 2016). Thus, the following are hypothesised:

$\mathrm{H}_{1}$ : Brand satisfaction will have a significant positive influence on luxury brand attachment.

$\mathrm{H}_{2}$ : Luxury brand attachment will have a significant positive influence on brand loyalty.

$\mathrm{H}_{3}$ : Brand satisfaction will have a significant positive influence on brand loyalty.

This study uses the responses $(n=252)$ collected in the study 2 . The screening questions ensured that the respondents owned and used Giorgio Armani sunglasses at least once in their life time. The subsequent sections included the 8-item brand satisfaction scale (Sahin et al., 2011) and 4-item brand loyalty scale 
(Delgado-Ballester et al., 2003) scale. All items (Appendix 1) were measured on a 7-point Likert scale (1 = "strongly disagree" and 7 = "strongly agree").

Structural Equation Modelling with AMOS 24.0 was used for testing the model and proposed hypotheses. The measurement model provided a good fit with $\mathrm{x}^{2}=117.057, \mathrm{df}=51, \mathrm{x}^{2} / \mathrm{df}=2.295, \mathrm{RMSEA}=0.07, \mathrm{SRMR}=0.065$, $\mathrm{CFI}=0.975$, and $\mathrm{TLI}=0.968$. Moreover, the composite reliabilities (Brand satisfaction: 0.867, Luxury brand attachment: 0.951, and Brand loyalty: 0.865) and the AVE's (Brand satisfaction: 0.624, Luxury brand attachment: 0.762 , and Brand loyalty: 0.763 ) provided internal consistency and convergent validity. The discriminant validity was achieved as the pair-wise inter-construct correlations were smaller than the square root of the AVE values for the construct (Fornell and Larcker, 1981). The structural model also provided a very good model fit holding the same fit indices of the measurement model. All the three hypotheses were supported $(p<0.01)$. Brand satisfaction positively influences luxury brand attachment $(\beta=0.786, t=10.281)$ and brand loyalty ( $\beta=0.208, t=2.708$ ). As postulated, luxury brand attachment has positive impact on brand loyalty $(\beta=0.697, t=9.215)$. It is noteworthy that compared to brand satisfaction, luxury brand attachment has a stronger impact on brand loyalty. The result reinforces the importance of luxury brand attachment with the notion that mere brand satisfaction might not be adequate to build brand loyalty. A summary of measurement model fit indices for study 3,4 , and 5 is presented in Table 5.

Table 5 - Measurement model fit indices

\begin{tabular}{rccccccc}
\hline & $\mathrm{X}^{2}$ & $\mathrm{df}$ & $\mathrm{X}^{2} / \mathrm{df}$ & SRMR & RMSEA & CFI & TLI \\
\hline Study 3 & 17.215 & 14.000 & 1.230 & 0.019 & 0.032 & 0.998 & 0.996 \\
Study 4 & 401.731 & 195.000 & 2.060 & 0.060 & 0.060 & 0.963 & 0.956 \\
Study 5 & 117.057 & 51.000 & 2.295 & 0.065 & 0.070 & 0.975 & 0.968 \\
\hline
\end{tabular}

\section{CONCLUDING COMMENTS}

The development and validation of luxury brand attachment scale fulfils a number of key gaps in the luxury branding literature. As mentioned earlier, one of the key limitations with studies in luxury branding research is the lack of an accurate scale to measure luxury brand attachment and researchers have called for more accurate measures (e.g., Sung et al., 2015; Sreejesh et al., 2016). This paper fulfils this research gap by conceptualising and providing empirical support for the luxury brand attachment scale. This research establishes that luxury brand attachment is a unique construct that captures the essence of consumers' emotional connection to luxury brands. The luxury brand attachment scale provides an improved and more accurate measure for a better understanding of the consumer's attachment with luxury brands.

The usage of real-life advertisements as the survey stimuli provides ecological validity of the research. Similarly, surveying the luxury consumer panels and interviewing luxury branding academics and practitioners provide conceptual reliability of the construct. This research also validates the role of perceived 
self-congruence on consumers' luxury brand attachment. In addition, the predictive power of luxury brand attachment has been tested and it shows a significant positive correlation with consumer advocacy.

From a managerial viewpoint, the luxury brand attachment scale will facilitate the managers in segmenting the luxury consumers. This scale will be useful for luxury brand managers in three ways; (1) Luxury managers can understand the strength of the bond between consumer and luxury brand. (2) They can also identify the highly attached consumers who will not only remain loyal to brand but also advocate the brand to others (e.g., Tesla motor's customer story). Such consumer advocacy will increase the consumer base through attracting new consumers and will reduce the promotional expenditures. (3) Brand strategists can also engage the highly attached consumers in brand communities (e.g., travel for Louis Vuitton, horse riding for Hermes). Those consumers will act as the brand evangelists in the high net worth network. The recommendations from existing consumers are expected to results in a strong brand credibility to the potential consumers.

It has been apparent in the branding literature that highly attached consumers are willing to pay more for the brand, tend to switch less, get involved in brand-community, and show resilience to negative information about the brand (e.g., Japutra et al., 2014; Xie and Peng, 2009). All these behavioural intentions create a positive impact on the overall brand equity. Studies suggest that a strong and enduring psychological intimacy with the brand continuously provides a sense of joy, pleasure and happiness (e.g., Ben-Shahar, 2007; Cacioppo and Patrick, 2008) and thus the consumers are expected to continue the reciprocal relationship for an extended period of time (Aksoy et al., 2015). Thus, it would be easier for the luxury brand managers to identify and target highly attached consumers with personalised messages to maintain a strong bond with the brand. For example, the perceived sense of closeness with the brand can be strengthen by sending greetings on the consumers' personal occasions (e.g. birthday). Additionally, exclusive offers and priority options to buy limited edition luxury products will reinforce the enduring affinity between the consumer and brand. Overall, building and maintaining a deep emotional connection between consumer and brand is vital for a long-term profitable customer relationship. The luxury brand attachment scale would be the strategic tool to measure the strength of the consumer-brand connection.

Luxury brand managers can also leverage the attachment in extending the brand portfolio. Consumers with high luxury brand attachment are expected to show positive attitude toward the new offerings from the parent brand. Thus, cultivating and nurturing a strong emotional bond with consumers will make a positive impact on the luxury brand's extension success.

Furthermore, the growth of counterfeit luxury products and popularity of affordable 'masstige' and 'massclusive' luxury brands have diluted the consumers' desire for exclusive luxury brands. Luxury brand managers should emphasise on building an emotional connection between the consumer and brand to protect and nourish the sense of exquisiteness offered by luxury brands. This invisible barrier will help protect the luxury brands from counterfeits, masstige and massclusive products. 
Advertising managers can benefit from luxury brand attachment scale in several ways. They can understand which components of the measurement highly reflect the consumers' attachment to a particular luxury brand. Thereafter, that component can be portrayed in the advertising campaigns. For instance, 2015 Be Dior advertising campaign illustrates a series of printed advertisements in which Jennifer Lawrence preciously holds the Dior handbag (Cichowski, 2015) and the execution of the message shows her passion and connection toward the brand. Another example could be Tom Ford's Neroli Portofino 2011 campaign, which features a couple frolicking in the shower (Wischhover, 2011), builds on the consumers' perceived sense of joy and pleasure from the brand. Consumers' perceived luxury brand attachment might be enhanced by communicating the extreme beauty and delicacy (i.e. exquisiteness) of the luxury brand. Advertising campaigns may also render the luxury brand attachment by demonstrating storyboard on the inseparable bond between consumer and the luxury brand.

Another implication of luxury brand attachment would be to incorporate the consumers' perceived selfconcept into the advertising messages. Although Malär et al. (2011) suggest authentic and aspirational branding for emotionally attached consumers, very little is known about the relationship between consumers' brand-self congruence and luxury brand attachment. Luxury managers need to identify which aspect of the consumers' perceived selves has greater impact on luxury brand attachment. Thereafter, the particular self (actual or ideal) should be reflected on the advertising campaign to reinforce the level of attachment.

\section{Limitations and future research}

Although a comprehensive approach was undertaken in the scale development process, there are few limitations of this research. First, this research tests the scale only across the affordable to intermediate luxury products. Additional research should test the scale for inaccessible luxury products (e.g. Rolls-Royce, Bentley). Second, the scale needs to be validated in the luxury services context (e.g. luxury hotel, spa). Third, this research focused on the publicly visible products, however it would be imperative to examine the generalisability of the scale for privately consumed luxury branded products (e.g. undergarments, perfume). Future research may consider invariance test for the scale between actual and aspirational luxury consumers. In addition, the impact of luxury brand attachment on brand trust, satisfaction, commitment, and other consumer-brand related constructs should be examined. Empirical support is also required to identify the moderating and mediating variables that may influence the relationships among the antecedents and outcomes of the luxury brand attachment. 


\section{REFRENCES}

Ainsworth, M. D. (1982). Attachment: Retrospect and prospect. In C. M. Parkes and J. Stevenson-Hinde (Eds.), The place of attachment in human behaviour (pp. 3-30). New York: Basic Books.

Aksoy, L., Keiningham, T. L., Buoye, A., Larivière, B., Williams, L., \& Wilson, I. (2015). Does loyalty span domains? Examining the relationship between consumer loyalty, other loyalties and happiness. Journal of Business Research, 68(12), 2464-2476.

Albert, N., Merunka, D., \& Valette-Florence, P. (2008). When consumers love their brands: Exploring the concept and its dimensions. Journal of Business Research, 61(10), 1062-1075.

Alleres, D. (1990). Luxury-Strategies Marketing. Paris: Economica.

Aron, A., \& Aron, E. N. (1986). Love and the expansion of self: Understanding attraction and satisfaction. Hemisphere Publishing Corp/Harper \& Row Publishers.

Atwal, G., \& Williams, A. (2009). Luxury brand marketing-The experience is everything! Journal of Brand Management, 16(5), 338-346.

Bain, M. (2017, January, 4). In 2017's "new normal," luxury brands will have to work a lot harder to sell their pricey goods. Quartz. Retrieved from https://qz.com/876963/in-2017s-new-normal-luxury-brandswill-have-to-work-a-lot-harder-to-sell-their-pricey-goods/

Ball, A. D., \& Tasaki, L. H. (1992). The role and measurement of attachment in consumer behavior. Journal of Consumer Psychology, 1(2), 155-172.

Batra, R., Ahuvia, A., \& Bagozzi, R. P. (2012). Brand love. Journal of Marketing, 76(2), 1-16.

Belaid, S., \& Behi, A. T. (2011). The role of attachment in building consumer-brand relationships: an empirical investigation in the utilitarian consumption context. Journal of Product \& Brand Management, 20(1), 37-47.

Belk, R. W. (1988). Possessions and the extended self. Journal of Consumer Research, 15(2), 139-168.

Ben-Shahar, T. (2007). Happier: Learn the secrets to daily joy and lasting fulfilment. New York, NY: McGrawHill Companies.

Bowlby, J. (1979). The making and breaking of affectional bonds. London: Tavistock.

Brakus, J. J., Schmitt, B. H., \& Zarantonello, L. (2009). Brand experience: what is it? How is it measured? Does it affect loyalty? Journal of Marketing, 73(3), 52-68.

Briggs, F. (2016, April 20). Luxury Brands Fail To Segment And Target Customers Strategically In Email Marketing, Study Finds. Forbes. Retrieved from https://www.forbes.com/sites/fionabriggs/2016/04/20/luxury-brands-fail-to-segment-and-targetcustomers-strategically-in-email-marketing-study-finds/\#1 f967400f660

Cacioppo, J. T., \& Patrick, W. (2008). Loneliness: Human nature and the need for social connection. New York, NY: WW Norton \& Company.

Carroll, B. A., \& Ahuvia, A. C. (2006). Some antecedents and outcomes of brand love. Marketing Letters, 17(2), 79-89.

Cheah, I., Phau, I., Chong, C., \& Shimul, A. S. (2015). Antecedents and outcomes of brand prominence on willingness to buy luxury brands. Journal of Fashion Marketing and Management, 19(4), 402-415. 
Chelminski, P., \& Coulter, R. A. (2011). An examination of consumer advocacy and complaining behavior in the context of service failure. Journal of Services Marketing, 25(5), 361-370.

Chen, Q., \& Wells, W. D. (1999). Attitude toward the site. Journal of Advertising Research, 39(5), 27-38.

Churchill Jr, G. A. (1979). A paradigm for developing better measures of marketing constructs. Journal of Marketing Research, 64-73.

Cichowski, H. (2015, February 24). Jennifer Lawrence's New Ad Campaign Proves Frizzy Hair And Simple Makeup Can Be Stunning. The Gloss. Retrieved from http://www.thegloss.com/fashion/jenniferlawrence-new-dior-campaign-2015-hair-makeup-photos/

Cristini, H., Kauppinen-Räisänen, H., Barthod-Prothade, M., \& Woodside, A. (2017). Toward a general theory of luxury: Advancing from workbench definitions and theoretical transformations. Journal of Business Research, 70, 101-107.

D'Arpizio, C., Levato, F., Kamel, M., de Montgolfier, J. (2017). "LUXURY GOODS WORLDWIDE MARKET STUDY, FALL-WINTER 2017: The New Luxury Consumer Why Responding to the Millennial Mindset Will Be Key". Retrieved from http://www.bain.de/Images/BAIN_REPORT_Global_Luxury_Report_2017.pdf, Accessed on 10 March 2018.

De Barnier, V., Falcy, S. and Valette-Florence, P. (2012). Do consumers perceive three levels of luxury? A comparison of accessible, intermediate and inaccessible luxury brands. Journal of Brand Management, 19(7), pp.623-636.

Delgado-Ballester, E., Munuera-Aleman, J. L., \& Yague-Guillen, M. J. (2003). Development and validation of a brand trust scale. International Journal of Market Research, 45(1), 35-54.

DeVellis, R.F. (2003). Scale Development: Theory and Application, $2^{\text {nd }}$ Edition, Sage Publications.

Dolich, I. J. (1969). Congruence relationships between self-images and product brands. Journal of Marketing Research, 6(February). 80-84.

Dubois, B., \& Laurent, G. (1994). Attitudes toward the concept of luxury: An exploratory analysis. Asia-Pacific Advances in Consumer Research, 1(2), 273-278.

Eastman, J. K., Goldsmith, R. E., \& Flynn, L. R. (1999). Status consumption in consumer behavior: Scale development and validation. Journal of Marketing Theory and Practice, 7(3), 41-52.

Erdem, T., \& Swait, J. (2004). Brand credibility, brand consideration, and choice. Journal of Consumer Research, 31(1), 191-198.

Esch, F. R., Langner, T., Schmitt, B. H., \& Geus, P. (2006). Are brands forever? How brand knowledge and relationships affect current and future purchases. Journal of Product \& Brand Management, 15(2), 98105.

Fornell, C., \& Larcker, D. F. (1981). Structural equation models with unobservable variables and measurement error: Algebra and statistics. Journal of Marketing Research, 382-388.

Fournier, S. (1998). Consumers and their brands: Developing relationship theory in consumer research. Journal of Consumer Research, 24(4), 343-373.

Gibbs, A. (2016, April 12). Why the luxury sector has to adjust to a 'new normal'. CNBC. Retrieved from https://www.cnbc.com/2016/04/12/why-the-luxury-sector-has-to-adjust-to-a-new-normal.html 
Gomelsky, V. (2016, October 31). 10 Thought Leaders On What Luxury Brands Must Do To Stay Relevant. Luxury Society. Retrieved from https://www.luxurysociety.com/en/articles/2016/10/10-thoughtleaders-what-luxury-brands-must-do-stay-relevant/

Hair, J. F., Anderson, R. E., Babin, B. J., \& Black, W. C. (2010). Multivariate data analysis: A global perspective (Vol. 7). Upper Saddle River, NJ: Pearson.

Hazan, C., \& Shaver, P. R. (1994). Attachment as an organizational framework for research on close relationships. Psychological inquiry, 5(1), 1-22.

Hennigs, N., Wiedmann, K. P., Klarmann, C., Strehlau, S., Godey, B., Pederzoli, D., ... \& Taro, K. (2012). What is the value of luxury? A cross-cultural consumer perspective. Psychology \& Marketing, 29(12), 10181034.

Holt, D. B. (2002). Why do brands cause trouble? A dialectical theory of consumer culture and branding. Journal of Consumer Research, 29(1), 70-90.

Hu, L. T., \& Bentler, P. M. (1999). Cutoff criteria for fit indexes in covariance structure analysis: Conventional criteria versus new alternatives. Structural Equation Modeling: A Multidisciplinary Journal, 6(1), 1-55.

Hudders, L. (2012). Why the devil wears Prada: Consumers' purchase motives for luxuries. Journal of Brand Management, 19(7), 609-622.

Hung, K. P., Huiling Chen, A., Peng, N., Hackley, C., Amy Tiwsakul, R., \& Chou, C. L. (2011). Antecedents of luxury brand purchase intention. Journal of Product \& Brand Management, 20(6), 457-467.

Jacoby, J., \& Olson, J. C. (1977). Consumer response to price: an attitudinal, information processing perspective. Moving Ahead with Attitude Research, 39(1), 73-97.

Japutra, A., Ekinci, Y., \& Simkin, L. (2014). Exploring brand attachment, its determinants and outcomes. Journal of Strategic Marketing, 22(7), 616-630.

Jiang, L., \& Cova, V. (2012). Love for luxury, preference for counterfeits-A qualitative study in counterfeit luxury consumption in china. International Journal of Marketing Studies, 4(6).

Kapferer, J. N., \& Bastien, V. (2009). The Luxury Strategy. Kogan Page, London.

Kapferer, J. N., \& Valette-Florence, P. (2018). The impact of brand penetration and awareness on luxury brand desirability: A cross country analysis of the relevance of the rarity principle. Journal of Business Research, 83, 38-50.

Kaufmann, H. R., Petrovici, D. A., Gonçalves Filho, C., \& Ayres, A. (2016). Identifying moderators of brand attachment for driving customer purchase intention of original vs counterfeits of luxury brands. Journal of Business Research, 69(12), 5735-5747.

Keller, K. L. (2017). Managing the growth tradeoff: Challenges and opportunities in luxury branding. In Advances in Luxury Brand Management (pp. 179-198). Palgrave Macmillan, Cham.

Kim, J., \& Joung, H. M. (2016). Psychological underpinnings of luxury brand goods repurchase intentions: Brand-self congruity, emotional attachment, and perceived level of investment made. Journal of Global Scholars of Marketing Science, 26(3), 284-299.

Lacœuilhe, J. (2000). L'attachement à la marque: proposition d'une échelle de mesure. Recherche et Applications en Marketing, 15(4), 61-77. 
Liu, F., Li, J., Mizerski, D., \& Soh, H. (2012). Self-congruity, brand attitude, and brand loyalty: a study on luxury brands. European Journal of Marketing, 46(7/8), 922-937.

Magids, S., Zorfas, A., \& Leemon, D. (2015). The New Science of Customer Emotions. Harvard Business Review, 76, 66-74.

Malär, L., Krohmer, H., Hoyer, W. D., \& Nyffenegger, B. (2011). Emotional brand attachment and brand personality: The relative importance of the actual and the ideal self. Journal of Marketing, 75(4), 35-52.

Malhotra, N. K. (2010). Marketing research: An applied orientation. Upper Saddle River, NJ: Pearson

Martin, I. M., \& Stewart, D. W. (2001). The differential impact of goal congruency on attitudes, intentions, and the transfer of brand equity. Journal of Marketing Research, 38(4), 471-484.

Mason, R. S. (1992). Modelling the demand for status goods. Journal of Consumer Research, 12(3), 341-352.

Mikulincer, M., \& Shaver, P. R. (2007). Boosting attachment security to promote mental health, prosocial values, and inter-group tolerance. Psychological Inquiry, 18(3), 139-156.

Mittal, B. (2016). Retrospective: why do customers switch? The dynamics of satisfaction versus loyalty. Journal of Services Marketing, 30(6), 569-575.

Moses, L. (2013, April 10). Rich People Are Less Loyal to Specific Brands. Adweek. Retrieved from http://www.adweek.com/brand-marketing/rich-people-are-less-loyal-specific-brands-148418/

Moussa, S. (2015). I may be a twin but I'm one of a kind: are brand attachment and brand love different names for the same construct? Qualitative Market Research: An International Journal, 18(1), 69-85.

Murray, P. N. (2016, October, 12). The Emotions of Luxury. Retrieved from https://www.psychologytoday.com/blog/inside-the-consumer-mind/201610/the-emotions-luxury

O'cass, A., \& Frost, H. (2002). Status brands: examining the effects of non-product-related brand associations on status and conspicuous consumption. Journal of Product \& Brand Management, 11(2), 67-88.

Oliver, R. L. (1980). A cognitive model of the antecedents and consequences of satisfaction decisions. Journal of Marketing Research, 460-469.

Oliver, R. L. (2010). Satisfaction: A behavioral perspective on the consumer. ME Sharpe. Inc., New York.

Orth, U. R., Limon, Y., \& Rose, G. (2010). Store-evoked affect, personalities, and consumer emotional attachments to brands. Journal of Business Research, 63(11), 1202-1208.

Park, C. W., Maclnnis, D. J., \& Priester, J. (2006). Brand attachment: Constructs, consequences, and causes. Foundations and Trends ${ }^{\oplus}$ in Marketing, 1(3), 191-230.

Park, C. W., MacInnis, D. J., Priester, J., Eisingerich, A. B., \& lacobucci, D. (2010). Brand attachment and brand attitude strength: Conceptual and empirical differentiation of two critical brand equity drivers. Journal of Marketing, 74(6), 1-17.

Parrott, W. G. (Ed.). (2001). Emotions in social psychology: Essential readings. Psychology Press.

Phau, I., \& Prendergast, G. (2000). Consuming luxury brands: the relevance of the 'rarity principle'. Journal of Brand Management, 8(2), 122-138.

Plutchik, R. (1980). A general psychoevolutionary theory of emotion. Theories of emotion, 1(3-31), 4.

Pourazad, N. and Pare, V. (2014) 'Emotional Brand Attachment: Antecedents and Consequences for Luxury Brands', 28th Australian and New Zealand Academy of Management Conference, (December). 1-43. 
Price, L. L., Feick, L. F., \& Guskey, A. (1995). Everyday Market Helping Behavior. Journal of Public Policy \& Marketing, 255-266.

Rindfleisch, A., Burroughs, J. E., \& Wong, N. (2009). The safety of objects: Materialism, existential insecurity, and brand connection. Journal of Consumer Research, 36(1), 1-16.

Romaniuk, J. (2013). What's (Brand) Love Got to do with it? International Journal of Market Research, 55(2), 185-186.

Roux, E., Tafani, E., \& Vigneron, F. (2017). Values associated with luxury brand consumption and the role of gender. Journal of Business Research, 71, 102-113.

Roy, S. K., Eshghi, A., \& Sarkar, A. (2013). Antecedents and consequences of brand love. Journal of Brand Management, 20(4), 325-332.

Sahin, A., Zehir, C., \& Kitapçı, H. (2011). The effects of brand experiences, trust and satisfaction on building brand loyalty; an empirical research on global brands. Procedia-Social and Behavioral Sciences, 24, 1288-1301.

Sarkar, A., Ponnam, A., \& Murthy, B. K. (2012). Understanding and measuring romantic brand love. Journal of Customer Behaviour, 11(4), 324-347.

Sarkar, J. (2017, April, 15). Young buyers to represent $40 \%$ of global market for personal luxury goods by 2025. The Economic Times. Retrieved from http://auto.economictimes.indiatimes.com/news/industry/young-buyers-to-represent-40-of-globalmarket-for-personal-luxury-goods-by-2025/58189294

Schmalz, S., \& Orth, U. R. (2012). Brand attachment and consumer emotional response to unethical firm behavior. Psychology \& Marketing, 29(11), 869-884.

Seo, Y., \& Buchanan-Oliver, M. (2015). Luxury branding: The industry, trends, and future conceptualisations. Asia Pacific Journal of Marketing and Logistics, 27(1).

Shukla, P., Banerjee, M., \& Singh, J. (2016). Customer commitment to luxury brands: Antecedents and consequences. Journal of Business Research, 69(1), 323-331.

Sirgy, M. J. (1982). Self-concept in consumer behavior: A critical review. Journal of Consumer Research, 9(3), 287-300.

Sirgy, M. J., Grewal, D., Mangleburg, T. F., Park, J. O., Chon, K. S., Claiborne, C. B., ... \& Berkman, H. (1997). Assessing the predictive validity of two methods of measuring self-image congruence. Journal of the Academy of Marketing Science, 25(3), 229-241.

So, J. T., Parsons, A. G., \& Yap, S. (2013). Corporate branding, emotional attachment and brand loyalty: the case of luxury fashion branding. Journal of Fashion Marketing and Management: An International Journal, 17(4), 403-423.

Sreejesh S., Sarkar, A., \& Roy, S. (2016). Validating a scale to measure consumer's luxury brand aspiration. Journal of Product \& Brand Management, 25(5), 465-478.

Straker, K., \& Wrigley, C. (2016). Emotionally engaging customers in the digital age: the case study of "Burberry love". Journal of Fashion Marketing and Management, 20(3), 276-299.

Sung, Y., Choi, S. M., Ahn, H., \& Song, Y. A. (2015). Dimensions of luxury brand personality: Scale development and validation. Psychology \& Marketing, 32(1), 121-132. 
Tajfel, H. (1974). Social identity and intergroup behaviour. Information (International Social Science Council), 13(2), 65-93.

Thomson, M., Maclnnis, D. J., \& Park, C. W. (2005). The ties that bind: Measuring the strength of consumers' emotional attachments to brands. Journal of consumer psychology, 15(1), 77-91.

Tsai, S. P. (2005). Impact of personal orientation on luxury-brand purchase value. International Journal of Market Research, 47(4), 429-454.

Vigneron, F., \& Johnson, L. W. (2004). Measuring perceptions of brand luxury. Journal of Brand Management, 11(6), 484-506.

Wells, W. D., Leavitt, C., \& McConville, M. (1971). A reaction profile for TV commercials. Journal of Advertising Research. vol. 11 (December), pp. 11-17.

Willcox, G. (1982). The Feeling Wheel: A tool for expanding awareness of emotions and increasing spontaneity and intimacy. Transactional Analysis Journal, 12(4), 274-276.

Wischhover, C. (2011, April 14). Good Morning! Tom Ford's Neroli Portofino Ads Feature a Steamy Shower Scene. Fashionista. Retrieved from https://fashionista.com/2011/04/good-morning-tom-fords-neroliportofino-ads-feature-a-steamy-shower-scene

Wong, N. Y., \& Ahuvia, A. C. (1998). Personal taste and family face: Luxury consumption in Confucian and Western societies. Psychology and Marketing, 15(5), 423-441.

Xie, Y., \& Peng, S. (2009). How to repair customer trust after negative publicity: The roles of competence, integrity, benevolence, and forgiveness. Psychology \& Marketing, 26(7), 572-589.

Young, V. M. (2017, May 9). Coach's Victor Luis Talks Kate Spade, Modern Luxury and Acquisitions. WWD. Retrieved from http://wwd.com/business-news/mergers-acquisitions/coach-victor-luis-kate-spademodern-luxury-acquisitions-mass-accessible-luxury-handbags-stuart-weitzman-10883678/ Accessed on 10 October 2017. 


\section{Appendix 1: Factor loading and reliabilities for the constructs (study 4 and 5)}

\begin{tabular}{|c|c|c|}
\hline & Factor & Cronbach's alpha \\
\hline & \multicolumn{2}{|l|}{ loading } \\
\hline Actual self-congruence & & 0.907 \\
\hline This brand is consistent with how I see myself. & 0.733 & \\
\hline This brand reflects who I am. & 0.771 & \\
\hline People similar to me use brand like this. & 0.833 & \\
\hline The kind of person who typically uses this brand is very much like me. & 0.846 & \\
\hline This brand is a mirror image of me. & 0.807 & \\
\hline Ideal self-congruence & & 0.904 \\
\hline This brand is consistent with how I would like to see myself. & 0.742 & \\
\hline People that I would like to be use this brand. & 0.760 & \\
\hline The kind of person whom I would like to be typically uses this brand. & 0.802 & \\
\hline This brand is a mirror image of the person I would like to be. & 0.642 & \\
\hline Consumer advocacy & & 0.918 \\
\hline I suggest others about this brand. & 0.792 & \\
\hline By sharing my experience with this brand, I assist other people. towards a similar experience. & 0.788 & \\
\hline It makes me feel good to tell others about this brand. & 0.871 & \\
\hline I have responsibility to society to tell others about my experiences with this brand. & 0.784 & \\
\hline I give suggestion to other people about the quality of this brand to help them have a similar & 0.816 & \\
\hline experience. & & \\
\hline Brand satisfaction & & 0.928 \\
\hline I am very satisfied with the service provided by this brand. & 0.834 & \\
\hline I am very satisfied with this brand. & 0.907 & \\
\hline This brand does a good job of satisfying my needs. & 0.904 & \\
\hline The service-products provided by this brand is very satisfactory. & 0.894 & \\
\hline I believe that using this brand is usually a very satisfying experience. & 0.862 & \\
\hline I made the right decision when I decided to use this brand. & 0.859 & \\
\hline I am addicted to this brand in some way. & 0.626 & \\
\hline Brand loyalty & & 0.841 \\
\hline I consider myself to be loyal to this brand. & 0.898 & \\
\hline I am willing to pay more for this brand than for other brands on the market. & 0.877 & \\
\hline If this brand is not available at the store, I would buy it in another store. & 0.803 & \\
\hline
\end{tabular}

